\title{
Acetylation-defective mutants of Ppary are associated with decreased lipid synthesis in breast cancer cells
}

\author{
Lifeng Tian ${ }^{1}$, Chenguang Wang ${ }^{1}$, Fred K. Hagen ${ }^{2}$, Michael Gormley ${ }^{1}$, Sankar Addya ${ }^{1}$, \\ Raymond Soccio ${ }^{3}$, Mathew C. Casimiro', Jie Zhou ${ }^{1}$, Michael J. Powell ${ }^{1}$, Ping $\mathbf{X u}^{4}$, \\ Haiteng Deng ${ }^{5}$, Anthony A. Sauve ${ }^{4}$ and Richard G. Pestell ${ }^{1}$ \\ ${ }^{1}$ Department of Cancer Biology, Sidney Kimmel Cancer Center, Thomas Jefferson University, Philadelphia, PA, USA \\ ${ }^{2}$ Department of Biochemistry and Biophysics, University of Rochester, Rochester, NY, USA \\ ${ }^{3}$ Division of Endocrinology, Diabetes, and Metabolism, Department of Medicine, Department of Genetics, and The Institute \\ for Diabetes, Obesity, and Metabolism, Perelman School of Medicine at the University of Pennsylvania, Philadelphia, PA, USA \\ ${ }^{4}$ Department of Pharmacology, Weill Medical College of Cornell University, York Avenue LC216, New York, NY, USA \\ ${ }^{5}$ Proteomics Resource Center, Rockefeller University, New York, NY, USA \\ Correspondence to: Richard G. Pestell, email: director@kimmelcancercenter.org
}

Correspondence to: Chenguang Wang, email: chenguang.g.wang@gmail.com

Keywords: acetylation; peroxisome proliferator-activated receptor gamma (Ppary); nuclear receptors; silent mating type information regulation 2 homolog 1 (SIRT1); lipogenesis.

Received: JULY 18, $2014 \quad$ Accepted: August 18, $2014 \quad$ Published: August 19, 2014

This is an open-access article distributed under the terms of the Creative Commons Attribution License, which permits unrestricted use, distribution, and reproduction in any medium, provided the original author and source are credited.

\section{ABSTRACT}

In our prior publications we characterized a conserved acetylation motif $(K(R)$ xxKK) of evolutionarily related nuclear receptors. Recent reports showed that peroxisome proliferator activated receptor gamma (PPARY) deacetylation by SIRT1 is involved in delaying cellular senescence and maintaining the brown remodeling of white adipose tissue. However, it still remains unknown whether lysyl residues 154 and 155 (K154/155) of the conserved acetylation motif (RIHKK) in Ppary1 are acetylated. Herein, we demonstrate that Ppary1 is acetylated and regulated by both endogenous TSA-sensitive and NAD-dependent deacetylases. Acetylation of lysine 154 was identified by mass spectrometry (MS) while deacetylation of lysine 155 by SIRT1 was confirmed by in vitro deacetylation assay. An in vivo labeling assay revealed K154/K155 as bona fide acetylation sites. The conserved acetylation sites of Ppary1 and the catalytic domain of SIRT1 are both required for the interaction between Ppary1 and SIRT1. Sirt1 and Ppary1 converge to govern lipid metabolism in vivo. Acetylation-defective mutants of Ppary1 were associated with reduced lipid synthesis in ErbB2 overexpressing breast cancer cells. Together, these results suggest that the conserved lysyl residues K154/K155 of Ppary1 are acetylated and play an important role in lipid synthesis in ErbB2-positive breast cancer cells.

\section{INTRODUCTION}

Peroxisome proliferator-activated receptor gamma $(\mathrm{PPAR} \gamma)$ is a member of the nuclear receptor (NR) superfamily, which functions as a ligand-dependent transcription regulator. Due to alternative splicing and differential promoter utilization, PPAR $\gamma$ exists in two isoforms, PPAR $\gamma 1$ and PPAR $\gamma 2$. The murine Ppar 2 encodes an additional 30 amino acids (28 amino acids in human PPAR $\gamma$ ) at its $\mathrm{N}$-terminus. PPAR $\gamma 1$ is expressed in many tissues at low levels, while PPAR $\gamma 2$ is expressed at high levels and is restricted to adipose tissue. Mouse PPAR $\gamma 1$ and human PPAR $\gamma 1$ shared 98\% homology in protein sequence. PPAR regulates diverse biological functions including adipocyte differentiation [1], lipogenesis [2], inflammation [3], insulin sensitivity [4], cellular proliferation [5], and autophagy [6]. Both natural ligands including prostaglandins (15d-PGJ2) and synthetic ligands including the anti-diabetic thiazolidinediones (TZD) are known to induce PPAR $\gamma$ activity. 
PPAR $\gamma$ activity is also regulated by posttranslational modifications, including phosphorylation, sumoylation, ubiquitination and acetylation. Among these post-translational modifications, phosphorylation has been extensively studied. The Activation Function 1 (AF1) region of PPAR $\gamma$ is phosphorylated by mitogenactivated protein kinases (MAPKs) (PPAR $\gamma 1$ at Ser82 and PPAR $\gamma 2$ at Ser112), which represses transcriptional activity by inhibiting ligand binding and altering cofactor recruitment [7-9]. Phosphorylation of the same residue by cyclin-dependent kinases, $\mathrm{Cdk} 7$ and $\mathrm{Cdk} 9$, promotes PPAR $\gamma$ activity [10, 11]. Recently it was reported that PPAR $\gamma 2$ is phosphorylated at Ser273 by cyclindependent kinase 5 (CDK5) [12]. Phosphorylation of PPAR $\gamma 2$ by CDK 5 inversely correlates with TZD-induced insulin sensitivity in human. These studies indicate that phosphorylation of PPAR $\gamma$ at different sites or even at the same sites results in different transcriptional and functional outcomes depending on the physiological context and the kinases involved. This phenomenon is well known among other post-translationally modified nuclear receptors. Several different acetylation sites (K266, 268, 302 , and 303) of estrogen receptor alpha (ER $\alpha)$ have been reported [13, 14]. Acetylation of ER $\alpha$ at lysine 266 and 268 enhances the DNA binding and transactivation activities of the receptor, however acetylation of lysine 302 and 303 suppresses the transactivation function. Recent publications showed that PPAR $\gamma$ is acetylated by $\mathrm{p} 300$ or CBP and deacetylated by silent mating type information regulation 2 homolog 1 (SIRT1). PPAR $\gamma$ acetylation participated in cellular senescence [15] and the brown remodeling of white adipose tissue (Lysine 268 and 293) [16]. Even though acetylation has been well characterized in the androgen receptor (AR) and ER $\alpha$ at a conserved lysine motif $(\mathrm{K}(\mathrm{R}) \mathrm{xxKK})$ which is shared amongst evolutionarily related nuclear receptors $[14,17$ 19], the function of this conserved lysine motif in Ppary $\square$ was not known.

Increased de novo fatty acid synthesis, which contributes to energy homeostasis and tumor growth, is a common feature of human tumors. The survival of breast cancer cells, especially those with ErbB2/Her2 overexpression, is highly dependent upon the lipid metabolism induced by Ppary, which protects cells from palmitate toxicity [20]. Our previously published work showed that a constitutively active Ppary 1 mutant ( $\mathrm{P} \gamma \mathrm{CA})$ collaborated with oncogenic ErbB2 to promote mammary tumor growth [21].

Herein, we characterized Ppary1 acetylation at the conserved lysine motif (RIHKK). Our studies revealed that Ppary 1 is acetylated at nine distinct lysyl residues. The acetylation of Ppary 1 lysine 154 was confirmed by a chemically modified trypsin mapping protocol developed for histone acetylation mapping. The K155 residue, which is located in close proximity to the DNA binding domain, was deacetylated by SIRT1. The Ppary 1 mutant
K154/155R reduced the acetylation levels assessed by in vivo labeling. The acetylation-defective mutant K154/155A or K154/155Q showed reduced interaction with SIRT1. The Ppary1 K154/155 determines the induction of lipogenesis in ErbB2 overexpressing breast cancer cells. Loss of SIRT1 function and gain of Ppary 1 function converge on common gene signaling pathways. In summary, these results suggest that the acetylation of the conserved lysine motif (K154/155) of Ppary1 determines lipid synthesis in ErbB2-positive breast cancer cells.

\section{RESULTS}

\section{Acetylation of lysyl residues of conserved motif in Ppary}

Ppary acetylation has historically been investigated by using anti-acetyl lysine antibodies $[15,16]$. In order to determine Ppary acetylation, we firstly performed in vivo labeling assays. The incorporation of $\left[{ }^{3} \mathrm{H}\right]$ acetylCoA into Ppary was only seen in cells transfected with 3xFLAG-tagged Ppary1, but not control vector (Fig. 1A). The addition of trichostatin A (TSA), an inhibitor of type I/ II HDACs, or nicotinamide (NA), an inhibitor of Sirtuins, increased $\left[{ }^{3} \mathrm{H}\right]$-labeled Ppary (Fig. 1A). These results suggest that the basal acetylation levels of Ppary are very low, and endogenous class I/II and III HDACs are both involved in the deacetylation of Ppary.

The residues in proximity to Ppary 1 K154/155 resemble the acetylated motif of $\mathrm{ER} \alpha$ and $\mathrm{AR}[14,17]$ and are conserved among different species (Fig. 1B). In order to determine whether the lysyl residues K154 and K155 in the conserved motif of Ppar $\gamma$ are acetylated, we conducted mass spectrometry (MS) of immuneprecipitated 3xFLAG-tagged Ppary1 from HEK 293 cells. These lysyl residues contain numerous basic amino acids which are often resistant to conventional trypsin mapping. This was confirmed by trypsin and chymotrypsin mapping (Fig. S1A), which demonstrated that mapping covered $92 \%$ of the protein, but omitted the conserved acetylation motif. Therefore, trypsin mapping was conducted using a chemical-derivatization protocol [22]. While the sequence coverage (Fig. S1B) is not as high as conventional trypsin or chymotrypsin mapping, the spectral counts and Mascot scores for acetylated peptides were higher, and multiple peptides with overlapping sequences mapped to the same site (Fig. S2A, B). A total of nine lysyl residues including $\mathrm{K} 154$ were identified as targets for acetylation in vivo (Fig. 1C and Fig. S2A). Using 3-dimensional structural mapping, lysyl residues 156 and 157 of human PPAR $\gamma 1$ (lysyl residues 154 and 155 in mouse Ppary) are located in the DNA binding domain in close juxtaposition to the ligand binding domain (Fig. 1D). The side chain nitrogen of the K156 (K154 in mouse, bottom yellow residue) 
is approximately $8 \mathrm{~A}^{\circ}$ from the phosphate backbone of DNA, too far for a hydrogen bond, and therefore does not directly contact DNA (orange in image) but rather appears solvent accessible. This data is consistent with its observed acetylation by MS. The adjacent K157 (K155 in mouse, top yellow residue) side chain nitrogen is approximately $13 \mathrm{~A}^{\circ}$ from the DNA backbone, forms a hydrogen bond with E378 of human PPAR $\square \square$ but appears solvent inaccessible. To verify the acetylation of the conserved lysine motif in Ppar $\gamma$, an in vivo labeling assay was performed in HEK 293 cells transfected with 3xFLAG-tagged Ppary1 wild-type or K154/155R mutant. Wild-type Ppar 1 was acetylated while the K154/155R mutation significantly reduced the incorporation of $\left[{ }^{3} \mathrm{H}\right]$
acetyl-CoA (Fig. 1E), suggesting that K154/155 are bona fide acetylation sites.

As NA increased the Ppar $\gamma$ acetylation, we investigated whether Ppar 1 K154/155 could serve as a substrate for SIRT1. A synthetic peptide containing the sites was used as a substrate for an in vitro deacetylation assay. The kinetic parameters for deacetylation of this peptide were similar to that of a p53 peptide known to be deacetylated by SIRT1 (Fig. 1F). Confirmation of the peptide deacetylation (K155) was obtained by MS (Fig. $1 \mathrm{G}, \mathrm{H})$. Thus, consistent with our original findings [13, 17] in which the lysyl residues of a conserved motif (K(R) $\mathrm{xxKK}$ ) in ER $\alpha$ and AR are acetylated, and subsequent studies of other nuclear receptors (NRs) [18, 19, 23-25],
A

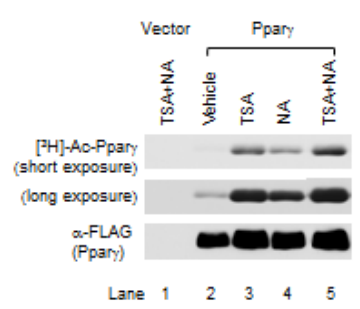

C

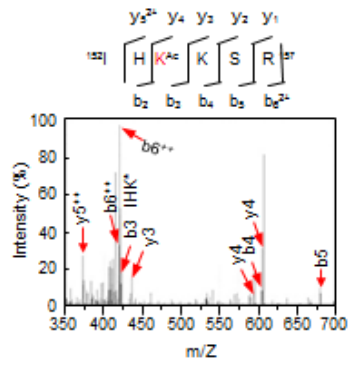

F

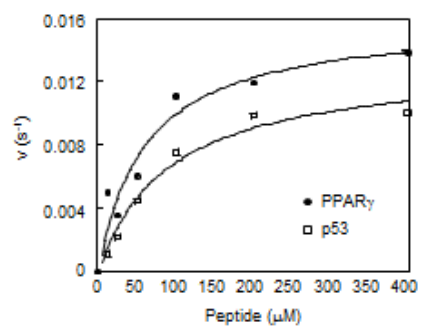

B Conserved Lysine motif

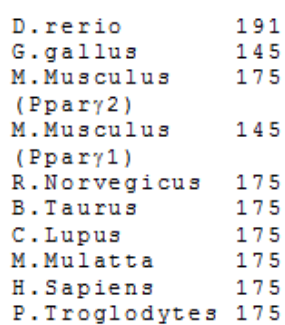

D
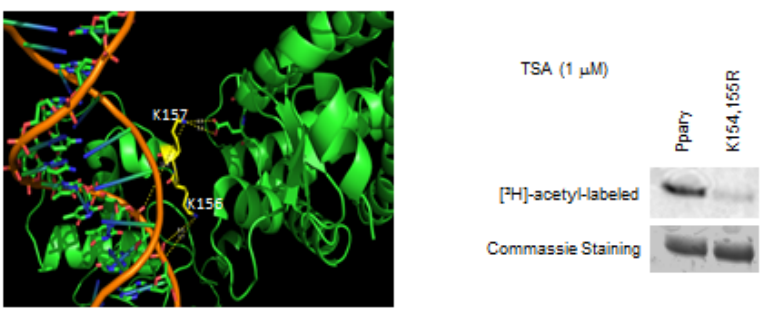

\section{$\underline{K(R) x x K K}$}

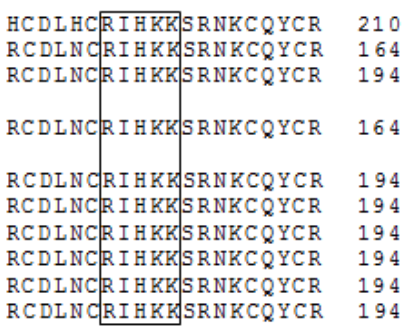

E
G

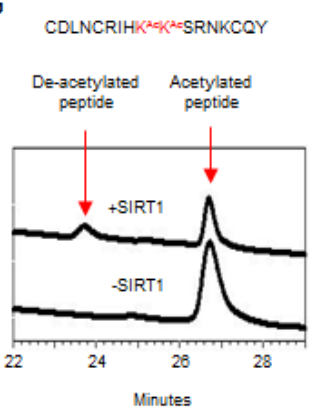

$\mathrm{H}$

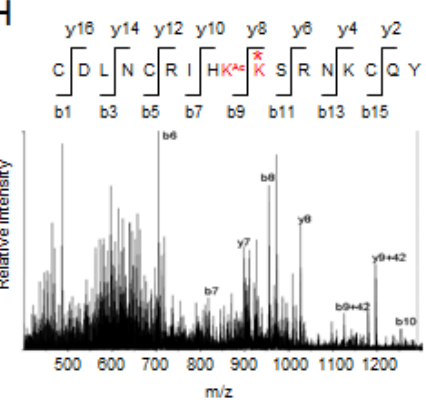

Figure 1: Acetylation of lysyl residues within conserved acetylation motif of Ppary. (A) The inhibition of either TSA-sensitive or NAD-dependent deacetylase activity induced Ppary acetylation assayed by in vivo $\left[{ }^{3} \mathrm{H}\right]$-sodium acetate labeling. (B) The conserved acetylation motif in Ppary is shown for several species. (C) Tandem MS (MS/MS) spectrum of Ppary showing the acetylation at K154 (Red letter), "Ac" indicates lysine (K) residues that is acetylated. (D) A cylinder model for the crystal structure of hPPAR $\gamma 1$ with DNA double helix (orange color). The lysine 156 and 157 are shown in yellow. (E) Mutant K154/155R significantly reduced Ppar $\gamma$ acetylation. (F) The deacetylation rate of Ppar $\gamma$ or 553 peptide of different concentrations by SIRT1. The lines are best fits to the Michaelis-Menten equation and determine the following values for $K_{m}$ and $V_{\max } \operatorname{PPAR} \gamma(\bullet), K m$ is $60.1 \mu \mathrm{M}$, vmax is $0.016 \mathrm{~s}-1$; ASp53 (b), Km is $90.5 \mu \mathrm{M}, v \max$ is $0.013 \mathrm{~s}-1$. (G) HPLC chromatograms of Ppary peptide deacetylation with SIRT1 enzyme. Untreated diacetylated Ppar $\gamma$ peptide is shown at bottom chromatogram. (H) MS/MS spectrum of the deacetylated Ppar $\gamma$. Asterisk indicated deacetylated lysine residue. 
Ppar 1 is also acetylated at the conserved lysine motif.

\section{Mutation of Ppary1 at K154/155 reduces SIRT1 binding}

The association between Ppar 1 and SIRT1 was next examined by immune-precipitation and Western
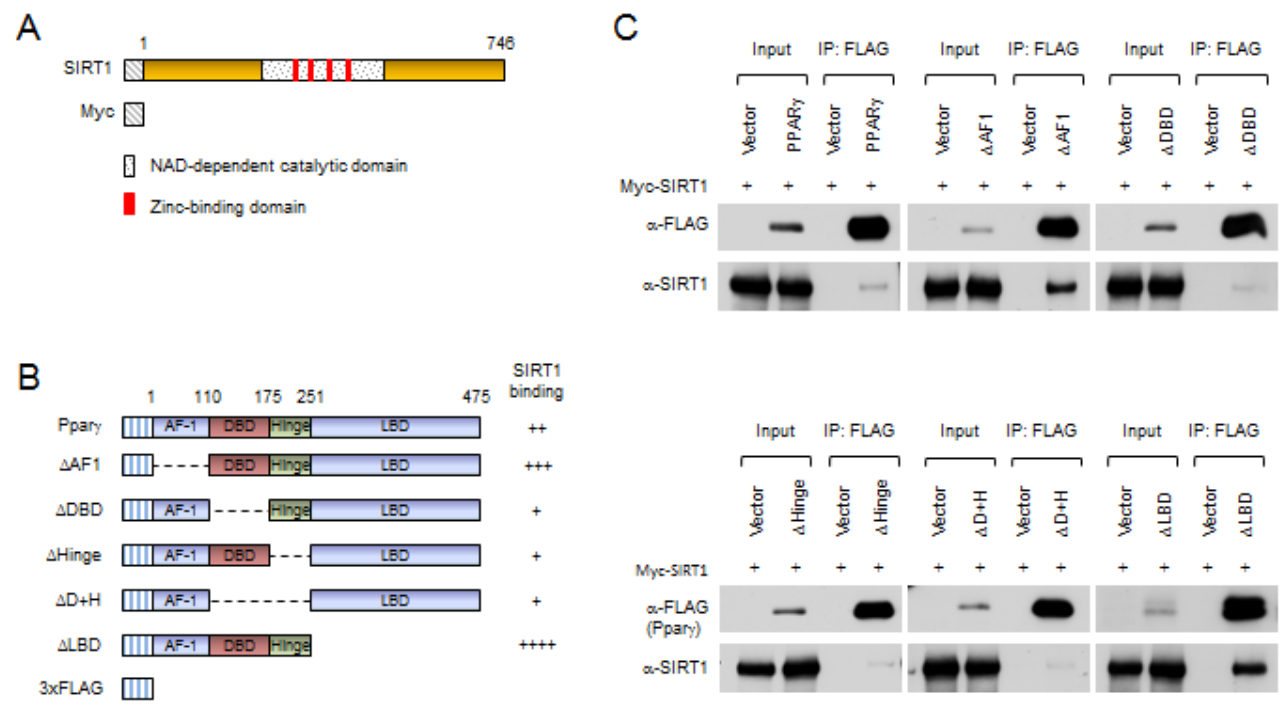

D

$E$

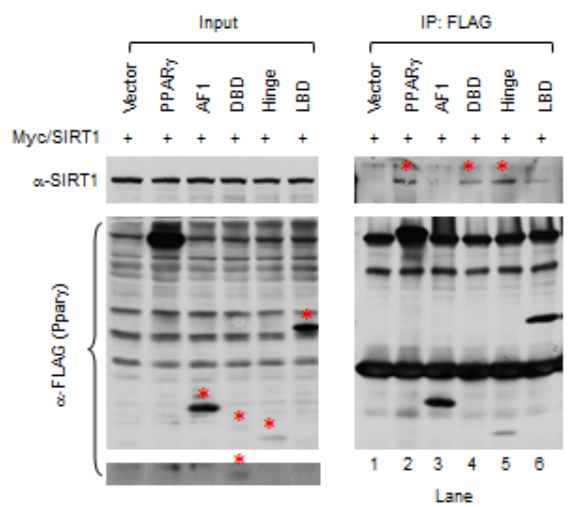

F

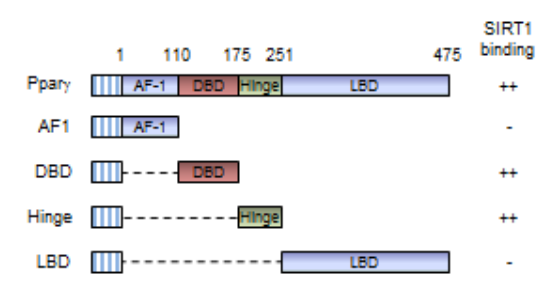

3xFLAG एI]

G

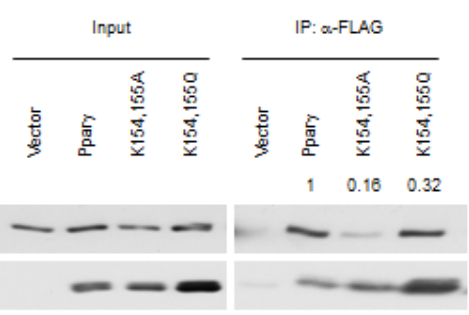

Figure 2: Mutation of Ppary at K154/155 reduces SIRT1 binding. (A) Schematic diagram of Myc-tagged SIRT1 wild-type. (B) Schematic diagrams of 3xFLAG-tagged Ppary1 full length and internal deletion mutants. (C) HEK 293T cells were transfected with the indicated plasmids. Immuno-precipitations with anti-FLAG antibody were conducted, and Western blot was performed by indicated antibodies. The abundance of SIRT1, PPAR $\gamma$ internal deletions in input are shown. (D) Schematic diagrams of 3xFLAG-tagged Ppar 1 full length and individual domains. (E) HEK 293T cells were transfected with the indicated plasmids. Immuno-precipitations with antiFLAG antibody were conducted, and Western blot was performed by indicated antibody. The bands for 3x FLAG-tagged Ppary full length and individual domains are indicated by an asterisk. (F) Schematic diagrams of 3xFLAG-tagged Ppary1, Myc-tagged SIRT1 wildtype and catalytic point mutation. (G) HEK 293T cells were transfected with the indicated plasmids. Immuno-precipitations with antiFLAG antibody were conducted, and Western blot was performed by indicated antibody. All experiments were performed at least 3 times, representative figures are shown. 
blot analyses. We firstly examined the domains of Ppar 1 required for SIRT1 binding. Expression vectors encoding Myc-tagged SIRT1 (Fig. 2A) together with FLAGtagged Ppar 1 or internal deletion mutants (Fig. 2B) were transiently introduced into HEK 293T cells. Immuneprecipitation was performed. Protein expression was evidenced by Western blot of the input protein using an anti-FLAG antibody for Ppar 1 and mutants, and an antiMyc antibody for SIRT1 (Fig. 2C). SIRT1 was detected in immune-precipitated wild-type Ppar $\gamma 1$. Deletion of the AF-1 domain or ligand binding domain (LBD) of Ppary 1 enhanced relative SIRT1 binding. Deletion of the DNA binding domain (DBD) and/or hinge region reduced binding (Fig. 2C). Given that deletion of the DBD and/ or hinge region reduced SIRT1 binding, we determined whether SIRT1 is associated with the individual DBD or hinge domains. Expression vectors encoding individual Ppary1 domains (Fig. 2D) were co-expressed with SIRT1 expression vector in HEK 293 T cells. Western blot with anti-Myc antibody showed either the DBD or hinge region of Ppary 1 was sufficient for association with SIRT1. The relative binding of SIRT1 to the AF1 region and LBD was reduced compared to wild-type Pparyl (Fig. 2E). We further studied the interaction between the Ppar $\gamma 1$ K154/155 mutation and SIRT1. As shown in Figure 2F and $2 \mathrm{G}$, both K154/155A and K154/155Q demonstrate reduced binding to SIRT1. These results suggest that the $\mathrm{DBD}$ and/or hinge regions of Pparyl are required for SIRT1 association and that both the K154/155A and the K154/155Q mutants have reduced SIRT1 binding ability.

B Liver

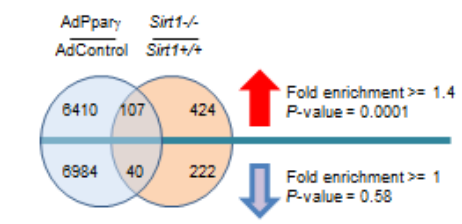

\section{C}

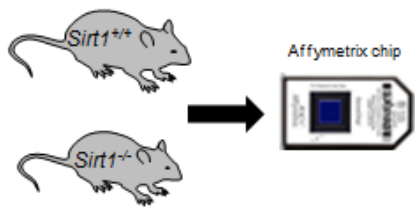

\begin{tabular}{|c|c|c|c|c|}
\hline \multirow{2}{*}{ KEGG Pathway } & \multicolumn{2}{|c|}{ Sirt1 Repressed } & \multicolumn{2}{|c|}{ PPARg induced } \\
\hline & Fold-enrichment & P-value & Fold-enrichment & P-value \\
\hline $\begin{array}{l}\text { Biosynthesis of unsaturated fatty } \\
\text { acids }\end{array}$ & 16.0 & $1.92 \mathrm{E}-09$ & 2.3 & 0.00034 \\
\hline Fatty acid metabolism & 13.6 & $7.78 \mathrm{E}-13$ & 2.2 & 0.00001 \\
\hline PPAR signaling pathway & 7.6 & $1.34 E-08$ & 1.6 & 0.00185 \\
\hline $\begin{array}{l}\text { Valine, leucine and isoleucine } \\
\text { degradation }\end{array}$ & 7.1 & $1.44 E-05$ & 1.4 & 0.04515 \\
\hline Pyruvate metabolism & 7.1 & 4.98E-05 & 1.5 & 0.04569 \\
\hline Peroxisome & 5.3 & $1.75 E-05$ & 1.6 & 0.00055 \\
\hline Glycerolipid metabolism & 4.2 & 0.00874687 & 1.5 & 0.02316 \\
\hline
\end{tabular}

D Fold enrichment

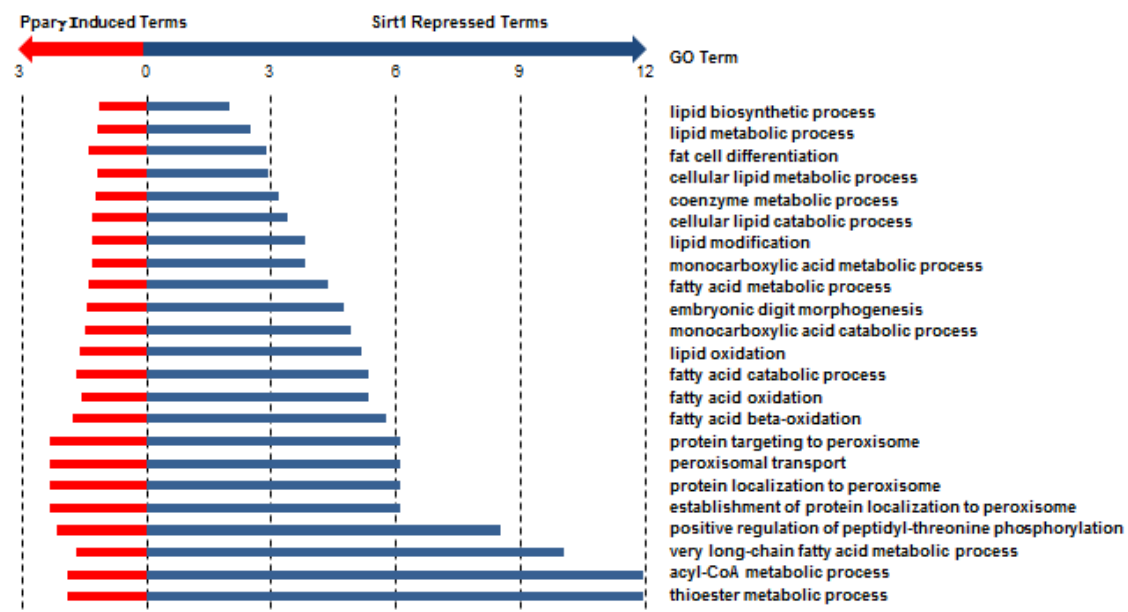

Figure 3: Sirt1 and Ppary are both required for maintaining essential metabolic pathways in the liver. (A) Schematic representation of microarray screening of deferentially expressed genes between Sirt $1^{-/}$mouse liver and Sirt ${ }^{+/+}$mouse liver. (B) Overlap of genes regulated by Ppary overexpression and Sirt1 knockout in mouse liver. (C) KEGG pathways enriched for genes up-regulated in Ppary $\square$ overexpressing and Sirt1 knockout liver. (D). Gene Ontology Biological Processes enriched for genes up regulated in Ppary overexpressing and Sirt1 knockout liver. Hypergeometric test used to identify deregulated ontologies associated with Ppary overexpression and Sirt1 knockout. Fold induction $\geq 1.5$ and $P$-value $\leq 0.05$. 


\section{SIRT1 deletion and Ppary gain-of-function govern common signaling pathways in vivo}

Given that Ppary enhances adipogenesis [26] and Sirt1 attenuates adipogenesis [27], we investigated the possibility that SIRT1 deletion and Ppary gain-offunction may have common gene expression signatures in vivo. Total RNA from liver samples was isolated from Sirt $1^{-1}$ mice and littermate controls [28]. Microarray analysis identified 262 genes that were significantly down-regulated and 531 genes that were significantly increased in Sirt $1^{-/}$mouse liver relative to Sirt ${ }^{+/+}$mouse liver $(P<0.05$, Fold $>1.5)$ (Fig. 3A, B and Table S1). Gene network analysis populated lipid metabolism as the major downstream target of Sirt1 (Tables S2). For the gene expression profile of Ppar gain-of-function, we took advantage of published data conducted in mouse liver injected with an adenovirus encoding mPpary 1 [29]. The hepatic genes altered in Sirt ${ }^{-/}$mice were compared to those regulated by Ppary 1 overexpression. A significant number of genes (107 genes with 76 expected giving a fold enrichment of 1.4 and a $P$-value of 0.0001 ) were up-regulated by Ppary1 overexpression and Sirt1 gene deletion (Fig. 3B). Seven KEGG pathways and 23 Biological Process Gene Ontologies were enriched for genes up-regulated by Ppary1 overexpression and Sirt1 gene deletion (Fig. 3C, D). Such pathways were mainly involved in lipid metabolism, including the biosynthesis of unsaturated fatty acids, fatty acid metabolism, and fatty acid oxidation. These data suggested SIRT1 and Ppary converge to govern lipid metabolism in vivo.

\section{The conserved acetylation sites of Ppary determine lipid production}

Given Sirt1 deacetylates Ppary and inhibits adipogenesis, we reasoned that acetylation of Ppary may promote lipid synthesis. In order to investigate the role of the conserved acetylation sites of Ppary in lipogenesis, ErbB2 overexpressing breast cancer cells were used and lysyl residues were substituted with alanine ( $\mathrm{K}$ to A) or glutamine ( $\mathrm{K}$ to $\mathrm{Q}$ ) to generate residues that were incapable of being acetylated. Substitution mutations (K154/155A, K154/155Q and K154/155R) of Ppary1 $\mathrm{K} 154 / 155$ were generated, and transduced into MCF10ANeuT cells. K77R of Ppary1, a Ppary mutant that is defective in SUMOylation [30, 31], was used as a positive control since this mutant induces adipogenesis in NIH3T3 cells. Following a differentiation protocol, Oil Red O staining followed by subsequent quantitative measurement was used to examine the lipid accumulation. Ppary induced lipid accumulation which was further enhanced by Ppary1 K77R (Fig. 4A). In contrast, the Ppary1 K154/155A and the K154/155Q mutants were defective in the induction of adipogenic differentiation and lipid accumulation (Fig. 4A, B). Consistent with the ability of Ppary to induce lipid formation, the relative protein abundance of the adipocyte Protein 2 (aP2) was induced by Ppary 1 and the Ppary1 K77R mutant but not the K154/155A or K154/155Q mutants (Fig. 4C). Under differentiation conditions, the expression levels of the cell cycle regulators, cyclin D1 and cyclin E, were slightly increased or unchanged respectively (Fig. 4C). Next, in order to study the gene expression profile regulated by Ppary acetylation, microarray analysis was performed. Genome-wide expression analysis identified 995 genes differentially expressed in Ppary1-transduced MCF10A-NeuT cells (Tables S3). Among these, pathway analysis identified 127 genes populating the enhanced lipid metabolism pathway (Fig. 4D and Tables S4). Key enzymes required for de novo lipogenesis and $\beta$-oxidation are upregulated (highlighted by orange color) by wildtype Ppary, but not K154/155A or K154/155Q substitution mutants (Fig. 4E). Comparison of the gene expression pathways regulated by Ppary vs. the K154/155Q (Fig. 4F) showed distinct pathways dependent upon the K154/155 with the loss-of-function (Fig. 4F, I and Tables S5) or gain-of-function (Fig. 4F, III and Tables S6). Unchanged pathways are shown in Tables S7. These data suggest that substitution of lysyl residues with residues that cannot be acetylated (alanine ( $\mathrm{K}$ to $\mathrm{A}$ ) or glutamine (K to $\mathrm{Q}$ )) represents PPAR $\gamma$ acetylation-defective mutant in and that Ppary acetylation at the conserved lysine motif serves as a molecular switch of Ppary-mediated induction of lipogenesis in breast cancer cells.

\section{DISCUSSION}

In this report, we have shown that the conserved acetylation site (K154/155) of Ppary plays a critical role in breast cancer cell lipid synthesis. Firstly, we identified nine distinct acetylation sites in cultured cells by MS, and further confirmed the acetylation of K154/155 of Ppary by in vivo labeling assay. We analyzed the function of K154/155 acetylation based on the conservation of this motif across species and evolutionally related nuclear receptors [14]. Our results showed that acetylationdefective mutants of Ppary are associated with decreased lipogenic differentiation in ErbB2-positive breast cancer cells, as shown by Oil Red O staining, protein expression of the classic adipocyte marker aP2, and mRNA expression of multiple lipogenic genes in microarray analysis. Decreased lipogenic function of the K154/155A and K154/155Q mutant was not due to changes of protein structure, cellular localization, and protein stability (unpublished data). This work provides a novel mechanism through which Ppary regulates lipid metabolism via conserved acetylation sites in breast cancer cells.

Acetylation is a dynamic post-translational modification of lysyl residues. Han et al. reported that 
A

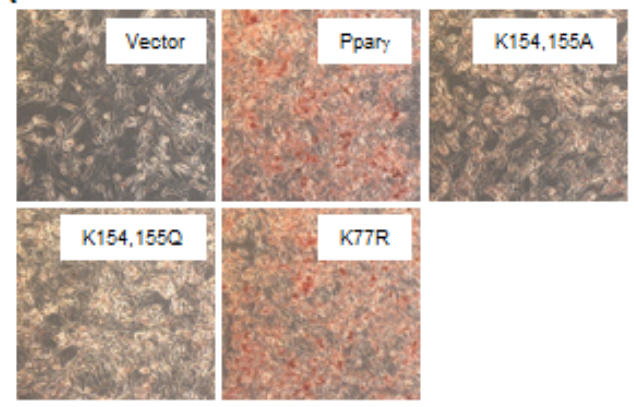

B

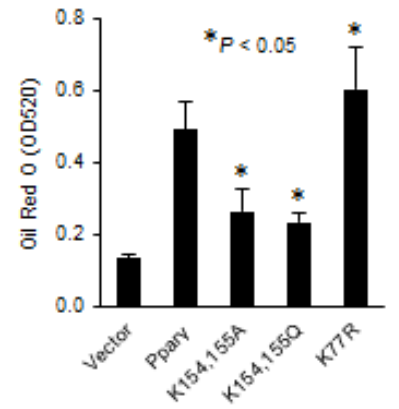

C

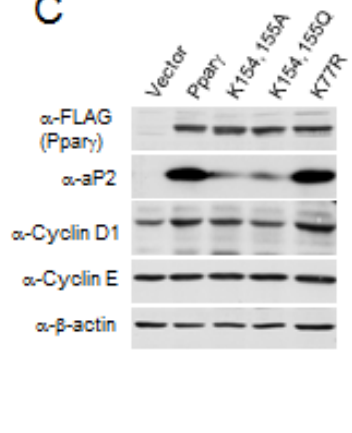

Lipid Metabolism

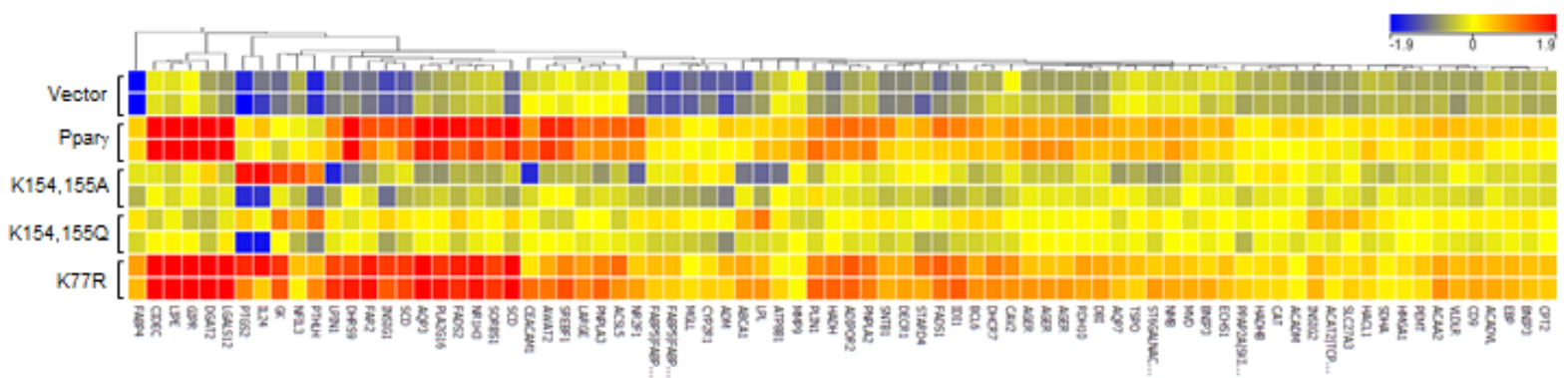

E

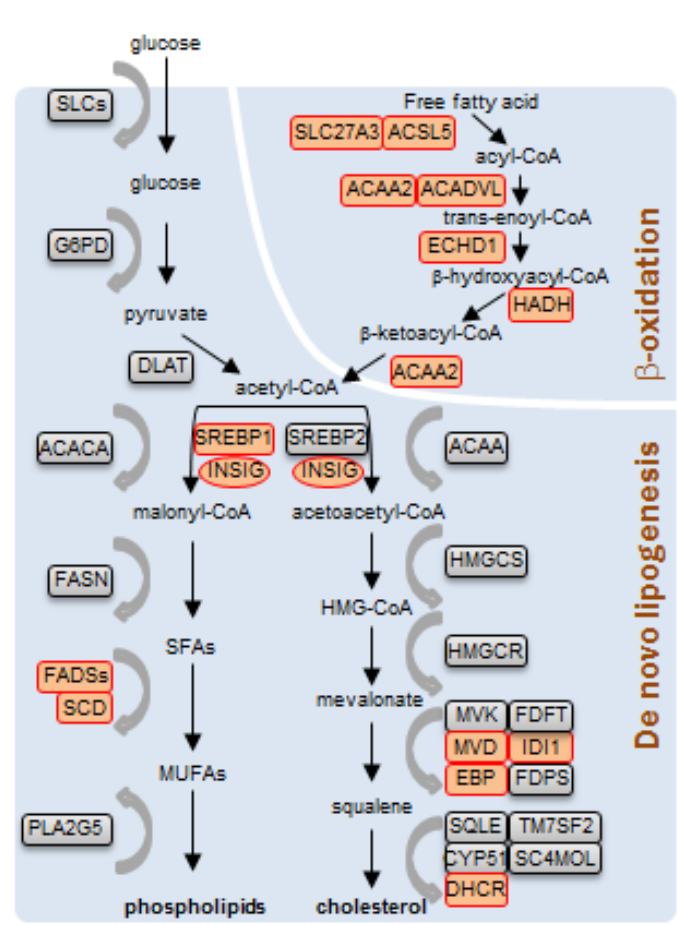

$\mathrm{F}$

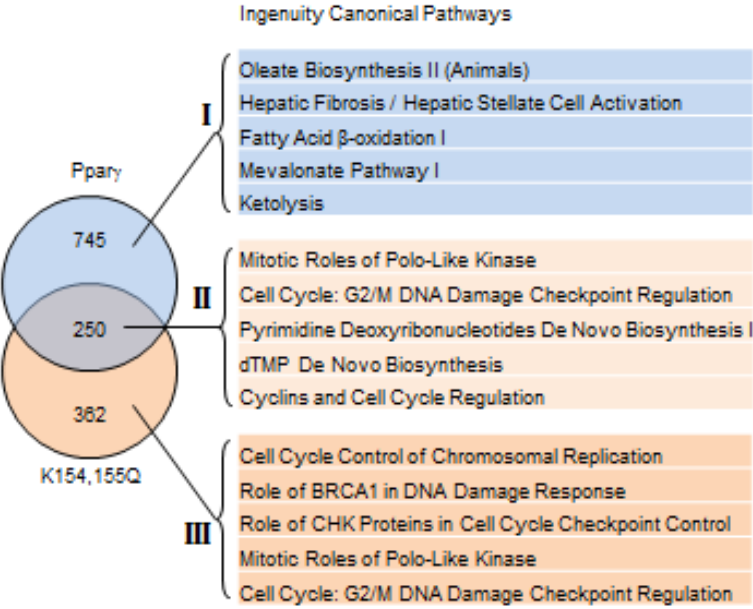

Figure 4: Acetylation-defective mutant of Ppary is associated with decreased lipogenesis. (A) MCF10A-NeuT cells expressing various mutants of Ppary were cultured until they were confluent, after 2 days, cells were stained with Oil Red O, and photographed. (B) Quantitative analysis of lipids in cells shown in (A) was performed by measuring the OD $520 \mathrm{~nm}$ of the Oil Red O stained cells eluted with 4\% Igepal CA-40 in isopropanol (v/v). The results are shown as the average of three experiments; the bars indicate mean \pm SEM. (C) Total cellular proteins from cells subjected to the same experimental protocol as in (A) were collected, and analyzed by Western blot as indicated. (D) Heat map of genes of lipid metabolism differentially regulated by Ppary and vector control. (E) Schematic representation of the key enzymes of lipogenic signaling pathway. Genes upregulated by Ppary are highlighted (orange color). (F) The genes differentially regulated in MCF10A-NeuT cells expressing wild-type Ppary or Ppary acetylation mutant were analyzed by the Ingenuity Pathway. The top five Canonical Pathways were listed corresponding to the loss of function with Ppary acetylation mutant (I), the gain of function (III) and those unchanged by acetylation (II). 
acetylation and deacetylation of Ppary is regulated by p300 and SIRT1 in the process of cell senescence [15], however no acetylated residues were identified. Recent publication by Li et al. mapped 5 acetylated lysyl residues $(98,107,218,268$, and 293) in mouse Ppary2 $(68,77$, 188,238 and 263 in mPpary 1) by MS [16]. Among them, two evolutionally conserved residues in the helix 2-helix region, Lys268 and Lys293 were further investigated. These studies indicated that deacetylation of Ppary at Lys 268 and Lys293 by SIRT1 is required for maintaining the brown remodeling of white adipose tissue [16]. However, these prior studies did not analyze acetylation of the conserved lysine motif (K(R)xxKK) in Ppary due to the limited coverage of the MS protocol used. Similar to the N-terminus of histone, the region "RIHKKSRNKC" is enriched with an overwhelming number of arginine and lysyl residues. Small fragments obtained by conventional trypsin digestion cannot be detected by conventional MALDI-TOF. Therefore, in our studies, trypsin mapping after a chemical-derivatization protocol was used to render lysine positions resistant to trypsin cleavage. This method increased the spectral counts and Mascot scores of acetylated peptides. A total of nine lysyl residues including K154 were identified. Among them, K188 and K238 in Ppary1 correspond to K218 and K268 in Ppary2, which were reported by Li et al [16]. Discrepancies in the identified Ppary acetylation sites may be the results of two different experimental approaches and/or the choice of Ppary isoform choose in these two studies. In our approach, we transfected HEK 293 cells with mPpar 1 , and treated with TSA and NA, while in their report, HEK 293 cells were co-transfected with expression vectors encoding mPpar 2 and acetyltransferase $\mathrm{Cbp}$, followed by treatment with Rosiglitazone (a PPAR $\gamma$ agonist). Quantification of K154/155 acetylation was performed. The results suggest that the native acetylation levels of Ppary are very low (1\%), consistent with Li et al [16] in which the acetylation of mPpary2 K268 and K293 was detected by MS only in the presence of Cbp. Acetylation of K155 was not detected by MS, most likely due to its inaccessibility by solvent as shown by a 3-dimensional structure analysis. Using an in vitro deacetylation assay, we demonstrated that a Ppary peptide harboring acetylated K154 and K155 residues is a substrate for SIRT1 deacetylation. Finally, in our in vivo labeling studies, the Ppary mutant K154/155R conveyed significantly reduced incorporation of $\left[{ }^{3} \mathrm{H}\right]$ acetyl-CoA. Together, these results demonstrate that K154 and 155 are bona fide acetylation sites in vivo and are substrates for SIRT1 deacetylation.

Han et al. reported the catalytic domain of SIRT1 is necessary and sufficient for the interaction between Ppary and SIRT1 and that the catalytically inactive SIRT1 mutant H363Y conveyed reduced association with Ppary [15]. In our studies, the DBD and/or hinge regions of Ppary were required for SIRT1 association. The K154/155A or K154/155Q mutants showed reduced association with SIRT1. These data are consistent with our MS data, where all nine acetylation lysyl residues identified by MS are located in the DNA binding domain and hinge domain of Ppary. Our results indicate that SIRT1 binds and deacetylates Ppary. This led us to investigate the pathways regulated by SIRT1 and Ppary in vivo. As expected, a significant number of genes (107 genes) were up-regulated by Ppary overexpression and Sirt1 gene deletion. KEGG pathways and Biological Process Gene Ontologies populated lipid metabolism as the major term, including the biosynthesis of unsaturated fatty acids, fatty acid metabolism, and fatty acid oxidation. Recent studies have shown that the function of SIRT1 in metabolic homeostasis requires NAD+-dependent deacetylase activity. Sterol regulatory element binding protein (SREBP) family proteins are critical regulators of lipogenesis and cholesterologenesis. Walker, et al. and Ponugoti, et al. showed that SIRT1 can directly deacetylate SREBPs, and that SIRT1 activity is important in the fasting-dependent attenuation of SREBP function $[32,33]$. Several other nuclear receptors regulated by acetylation and deacetylation are also involved in lipid metabolism [34, 35]. Li, et al. reported that SIRT1 directly deacetylates LXRs, resulting in increased LXRs turnover and enhanced target gene expression [34]. LXRs are nuclear receptors that function as cholesterol sensors and regulate whole body cholesterol and lipid homeostasis. SIRT1 also regulates bile acid homeostasis through direct deacetylation of FXR. Down-regulation of hepatic SIRT1 increases FXR acetylation with deleterious metabolic outcomes [35]. More recently, Li et al. showed that a gain-of-function SIRT1 promotes "browning" of WAT by deacetylating Ppary at Lys268 and Lys293 [16]. Herein, we showed that loss-of-function of SIRT1 and gain-offunction of Ppary converge on liver lipid metabolism. The interaction between Ppary and SIRT1 potentially controls the acetylation and deacetylation status of Ppary protein. Therefore, deacetylation of Ppary by SIRT1 could serve as a molecular switch that acts as key metabolic sensor.

Enhanced lipogenesis is a hallmark of cancer cells [36]. This especially holds true in ErbB2-positive human breast cancer cells, which have a high degree of fat storage [37]. We have previously shown that active Ppary promotes ErbB2-positive breast cancer growth through enhanced angiogenesis [21]. In the current study, we investigated the role of Ppary K154/155 acetylation on lipid production in ErbB2-positive breast cancer cells. Adipogenic differentiation assays were performed to evaluate the function of these mutants in MCF10A cells transformed with oncogene NeuT. Consistent with data from Yamashita et al., Ppary2 induced adipogenesis in NIH3T3 cells and a sumoylation-defective K107R mutant of Ppary 2 stimulates adipogenesis more robustly than the wild-type [31]. We showed that Ppary induced lipid accumulation in MCF10A-NeuT cells, and the K77R mutant of Ppary1 increased lipogenesis. Oil Red 
O staining, lipogenic protein expression and genomewide expression analysis indicated that both K154/155A and K154/155Q mutants were defective in the induction of lipid accumulation and adipogenic differentiation. As shown in Figure 4, key enzymes and transcription factors required for de novo lipogenesis (SREBP, Insig and SCD) and $\beta$-oxidation (ACAA and MCD) are up-regulated by Ppar $\gamma$ wild-type, but not K154/155A or K154/155Q mutants. K154/155R mutant exhibited similar effect to Ppary wild type (data not shown). In our prior publication, we showed that ER $\alpha$ acetylation governs ligand sensitivity, as all substitution mutants ( $\mathrm{K}$ to $\mathrm{A}, \mathrm{Q}$ and $\mathrm{R}$ ) induced $\mathrm{ER} \alpha$ hormone sensitivity [14]. Recently, Daniel et al. identified the progesterone receptor (PR) acetylation site within the conserved lysine motif KxKK (amino acids 638-641) [18]. Mutation of these three lysyl residues to alanine (A) or glutamine (Q) resulted in delayed phosphorylation, nuclear entry and transactivation of c-Myc, a known rapid response gene. In summary, SIRT1 deacetylates Ppary at a conserved lysine motif. SIRT1 deletion and Ppary gainof-function converge to govern lipid metabolism in vivo. We conclude that acetylation of Ppary increases lipid synthesis. These data suggest that the Ppar $\gamma$ acetylation of the lysine motif serves as a molecular switch governing Ppar $\gamma$-mediated induction of lipogenesis in ErbB2/ Her2 overexpressing breast cancer cells. It is of great importance to further investigate if lipogenesis regulated by acetylation of the Ppary lysine motif (K154/155) contributes to the progression of ErbB2-positive breast cancer.

\section{MATERIALS AND METHODS}

\section{Cell culture, plasmid DNA, and transfection}

The HEK293, HEK293 T cells were maintained in Dulbecco's Modification of Eagle's Medium (DMEM) supplemented with $10 \%$ fetal bovine serum, $1 \%$ penicillin, and $1 \%$ streptomycin. MCF10A-NeuT cells were cultured as previously described [38]. MCF10A-NeuT cells transduced with Ppary1 or mutants were maintained in Dulbecco's Modification of Eagle's Medium (DMEM) supplemented with $10 \%$ fetal bovine serum, $1 \%$ penicillin, and $1 \%$ streptomycin. All cells were cultured in humidified atmosphere with $5 \% \mathrm{CO}_{2}$ at $37^{\circ} \mathrm{C}$. Rosiglitazone and $15 \mathrm{~d}-\mathrm{PGJ} 2$ are from Cayman Chemical.

The expression vectors encoding mouse Ppary1 are previously described [39]. The Ppar 11 point mutants were derived by site-directed mutagenesis using sequencespecific primers. The wild-type and point mutants of Ppary 1 were individually cloned into p3xFLAG-CMV 10 vector (Sigma) and MSCV-IRES-GFP vector. The internal deletion mutants of Ppar 1 were subcloned into p3xFLAG-CMV 10 vector using sequence-specific primers. The individual domain of Ppary 1 was digested by XbaI/BamHI from GAL4-DBD-HA-Ppary1-AF1, DBD, Hinge and LBD (Gifts from Dr. Z. [40]), and then was subcloned into p3xFLAG-CMV 10 vector. The integrity of all constructs was confirmed by sequence analysis. The Myc-tagged wild-type and mutant (H363Y) SIRT1 expression constructs in pcDNA3.1 were previously described [41].

Cell transfection and infection were performed as previously described [42, 43]. Retroviruses were prepared by transient cotransfection of vector expressing Ppary1, mutants or empty vector together with the helper viral vector into $293 \mathrm{~T}$ cells using calcium phosphate precipitation. The retroviral supernatants were harvested $48 \mathrm{~h}$ after transfection and filtered through a $0.45 \mu \mathrm{m}$ filter. Mammary epithelial cells MCF10A-NeuT cells were incubated with fresh retroviral supernatants in the presence of $8 \mu \mathrm{g} / \mathrm{ml}$ polybrene for $24 \mathrm{hrs}$, cultured for a further $48 \mathrm{hrs}$, and subjected to different assays.

\section{In vivo $\left[{ }^{3} \mathrm{H}\right]$-acetyl-CoA labeling.}

Labeling of Ppary was conducted using the previously described protocol with some modifications [44]. Briefly, one 10-cm plate of 293 cells was used for in vivo acetyl group labeling. The cells transfected either with expression vector or control were maintained in DMEM w/ 10\% FBS at over $80 \%$ confluence. The cells were first were treated with $1 \mu \mathrm{M}$ TSA and $10 \mathrm{mM}$ NA for 4 hours, and then transferred to DMEM medium containing $1 \mu \mathrm{M}$ TSA, $10 \mu \mathrm{M}$ NA and $1 \mathrm{mCi} / \mathrm{ml}\left[{ }^{3} \mathrm{H}\right]$-sodium acetate $(75-$ $150 \mathrm{mCi} / \mathrm{mmol}$ ) (Perkin Elmer) for $1 \mathrm{hr}$. Cells were washed twice with ice-cold PBS and lysed in RIPA buffer with freshly added protease inhibitor cocktail supplemented with fresh DTT $(1 \mathrm{mM})$ and PMSF (1 mM). The lysates were centrifuged at $14,000 \mathrm{rpm}$ for $15 \mathrm{~min}$ at $4^{\circ} \mathrm{C}$. Supernatants were incubated with antibody conjugated to agarose beads, for 6 to $12 \mathrm{hrs}$ at $4^{\circ} \mathrm{C}$. Immunopurified proteins were resolved on SDS-PAGE gels. Gels were either staining with Coomassie blue and then dried, or directly dried and subjected to autoradiography at $-70^{\circ} \mathrm{C}$ for 2-4 weeks.

\section{Identification of Ppary acetylated lysine residue using MS}

Preparation and proteolytic digestion of Ppary: 3xFLAG-tagged Ppary1 was purified by immunoprecipitation, using anti-FLAG M2 affinity gel, and the bound material was eluted using a soft SDSelution protocol in order to selectively elute the bound recombinant protein and not the anti-FLAG antibody. This eluent was concentrated on a speedvac and further separated on SDS-PAGE and stained with Coomassie blue. The major band at $55 \mathrm{kDa}$ was cut. The gel pieces 
were completely dehydrated and subsequently reduced and alkylated. To improve coverage of the basic regions of Ppary 1 sequences, the gel isolated protein was mapped using a modified trypsin mapping protocol as below.

Chemical modification of lysine and tryptic mapping of acetylation site: Chemical modification was achieved after the reduction/alkylation steps. In detail, the gel was hydrated with $10 \mu \mathrm{l}$ of deuterated acetic anhydride, 20 $\mu \mathrm{l}$ of $100 \mathrm{mM} \mathrm{ABC}(\mathrm{pH} 8)$, and mixing. The acetylation reaction is fast and results in acidification of the solution, so $70 \mu \mathrm{l}$ of $100 \mathrm{mM}$ ABC is immediately added and the solution is incubated at $37^{\circ} \mathrm{C}$ for 5 minutes. The $\mathrm{pH}$ is measured within the first 5 minutes and adjusted to 7-8. After an additional 30 minute incubation at $37^{\circ} \mathrm{C}$, the supernatant is removed and the gel pieces are washed twice with water, and then dehydrated by successive washes (with vortexing, as above) in $100 \mu \mathrm{l}$ of $50 \mathrm{mM}$ $\mathrm{ABC}$, then $100 \mu 150 \mathrm{mM}$ ABC with $50 \%$ acetonitrile (50$\mathrm{ACN}$ ), and finally $100 \% \mathrm{ACN}$. This chemical treatment derivatized lysyl residues with a deuterated acetyl group (a 45Dalton mass increase) and rendered lysine positions resistant to trypsin cleavage. Deuterated acetic anhydride was used to allow differentiation from the native acetyl group (a 42 Dalton modification group).

Trypsin (200 ng in $50 \mu \mathrm{l}$ of $50 \mathrm{mM} \mathrm{ABC}$ ) is then added to hydrate the gel slices. After an hour at room temperature, additional $50 \mathrm{mM} \mathrm{ABC}$ and $10 \% \mathrm{ACN}$ was added to ensure that the gel pieces were always covered with solvent. The digest was transferred to $37^{\circ} \mathrm{C}$ and digested overnight. Next, the supernatant was transferred to LoBind tubes (Eppendorf) and the remaining peptides were extracted by adding sufficient 50\% ACN, 5\% Trifluoroacetic acid to cover the gels and by vortexing for 25 minutes. This step was repeated and each of the three supernatants were combined and lyophilized in a Speedvac.

Mass spectrometry analysis: Dehydrated peptides were resuspended in 5\% acetonitrile, $0.05 \%$ formic acid and immediately loaded on a nano-spray tip for LC-MS/ MS analysis. $10-15 \%$ of the peptide digest is loaded on a Magic C18 AQ (Michrom) nanospray tip, packed to $5 \mathrm{~cm}$. This tip was loaded, using a pressure bomb, and washed, after installation on the HPLC of a Thermo LTQ mass spectrometer, with 5\% methanol, $0.1 \%$ formic acid, for $10 \mathrm{~min}$ with a flow rate of $600 \mathrm{nl} / \mathrm{minute}$ (about 10 column volumes $=6.6 \mu \mathrm{l}$ ) The peptide digests were analyzed in an LC-MS/MS run, using a 5-15\% methanol gradient over 2.5 minutes, followed by a $15-60 \%$ methanol gradient for 67 minutes, a $60 \%$ methanol isocratic step of 4 minutes, ending with a 3 -minute $95 \%$ methanol step, with all solvents containing $0.1 \%$ formic acid. A full MS survey scan is performed every 3 seconds and the top 7 peaks are selected to produce MS/MS fragmentation spectrum. In order to confirm if K154/155 is acetylated, the same peptide digest was run a second time, under identical HPLC conditions. With the mass spectrometer programmed with an inclusion filter of $383-431 \mathrm{~m} / \mathrm{z}$ to select for doubly charged peptides in the size range of the IHKKSR hexa-peptide in its unmodified and fully derivatized states. This selective method allows for the determination of the relative frequency of the modified and unmodified IHKKSR peptides, by evaluating the spectral count ratios.

Mapping of proteolytic peptide fragments and acetylation sites: The MS and MS/MS fragmentation spectrum data were used in a Mascot search of the whole mouse proteome. To identify peptide sequences modified with acetyl groups, a custom database, containing the recombinant Ppary sequence, was also searched. The following search criteria were used for selecting fragmentation spectra that map to proteolytic peptides: peptide tolerance $=-0.8$ to +0.5 , a minimum ion score of 15 , and a fragmentation spectrum, containing fragment ions that either include or flank the acetylated amino acid position. Mascot searches were conducted, allowing for multiple positive charge-states, 2, 3, or 4 missed cleavage sites, fixed S-carboxyamidomethyl modification of cysteine and variable methionine oxidation and lysine acetylation. Mascot searches use trypsin digestion, but allow for 4 or 5 missed trypsin cleavages, and variable deuterated acetyl (45 Da) and native acetyl (42 Da) modification.

\section{Determination of the deacetylation site in Ppary peptide in vitro}

To determine the Michaelis-Menten curves of SIRT1-catalyzed deacetylation of Ppar $\gamma$ and p53, the Ppar $\gamma$ peptide CDLNCRIHXXSRNKCQY and the p53 peptide GSRAHSSHLXSXXGQSTSRHRXLMFXTEGPDSD where " $X$ " is AcK (Rockefeller Proteomics Resource) . The enzymatic reaction was initiated by adding SIRT1 into the solution containing the peptide. For the Ppar $\gamma$ peptide, the Ppar $\gamma$ peptide of different concentrations was incubated with $4 \mu \mathrm{M}$ SIRT1, $500 \mu \mathrm{M}$ NAD, and $500 \mu \mathrm{M}$ DTT in the $100 \mathrm{mM} \mathrm{KH}_{2} \mathrm{PO}_{4}$ buffer of $\mathrm{pH} 8$. The reaction was quenched with $10 \%$ TFA after 10 minutes incubation at $37^{\circ} \mathrm{C}$. The Ppary peptide and the deacetylated peptide were separated by HPLC (Hitachi LaChrom Elite HPLC system) using a C18 $5 \mu \mathrm{m}$ column (Waters) with gradient acetonitrile and $0.1 \%$ TFA as eluent. The areas of peaks for peptides were used for quantification. For the p53 peptide, the p53 peptide of different concentrations was incubated with $4 \mu \mathrm{M}$ SIRT1, $500 \mu \mathrm{M}$ NAD in $100 \mathrm{mM}$ $\mathrm{KH}_{2} \mathrm{PO}_{4}$ buffer of $\mathrm{pH} 8$ at $37^{\circ} \mathrm{C}$. The enzymatic product acetyl adenosine diphosphate ribose (AADPR) was monitored by HPLC using C18 column (Waters) with 20 $\mathrm{mM} \mathrm{NH} \mathrm{N}_{4} \mathrm{OAc}$ as eluent. The area of AADPR peak was used for quantification. The turnover rate versus the Ppar $\gamma$ peptide and p53 peptide concentration was fitted with Kaleida Graph software, and $K_{m}$ and $k_{\text {cat }}$ were determined. 
In order to determine the deacetylation site in the Ppar $\gamma$ peptide, $200 \mu \mathrm{M}$ Ppar $\gamma$ was incubated with $4 \mu \mathrm{M}$ SirT1 for 20 minutes in the reaction of $1.25 \mathrm{~mL}$. The deacetylated peptide was separated from the Ppary peptide by HPLC as previously described and collected. The lyophilized product was analyzed for mass spectrometry at the Proteomics Resource Center in the Rockefeller University. In the analysis, the samples of Ppar $\gamma$ and the deacetylated Ppar $\gamma$ were separately mixed with 50\% aqueous methanol solution (vol:vol=1:1) and loaded into a glass nanospray PicoTip (New Objectives). The samples were analyzed by nano-electrospray tandem mass spectrometry with an ABI QSTAR mass spectrometer.

\section{Immunoprecipitation and Western blot}

HEK293T or HEK293 cells were transfected with an expression vector as indicated in the figure. $24 \mathrm{~h}$ after transfection, the cells were harvested in cell lysis buffer (50 mM HEPES (pH 7.2), 150 mM NaCl, 1 mM EDTA, 1 mM EGTA, 1 mM DTT, 0.1\% TritonX-100) supplemented with protease inhibitor mixture (Roche Diagnostics). Whole cell lysates $(500 \mu \mathrm{g})$ were immunoprecipitated with $10 \mu 1$ of M2 beads (A2220; Sigma) or $2 \mu \mathrm{g}$ of antibodies as indicated. Immunoprecipitates were washed 5 times with cell lysis buffer and resolved by SDS-PAGE gel followed by Western blot with the indicated antibodies. Antibodies used were: anti- FLAG ${ }^{\circledR}$ M2 Affinity Gel (M2; Sigma), anti- PPAR $\gamma$ (H100 and E8), anti-SIRT1 (H-300), anticyclin E (M-20), anti-aP2 (C-15), anti- $\beta$-actin (C4) (Santa Cruz), and anti-cyclin D1 (DCS-6; Santa Cruz or Ab3; NeoMarker). The abundance of immunoreactive protein was quantified using a densitometer (Image Quant version 1.11, Molecular Dynamics Computing Densitometer, Sunnyvale, CA).

\section{Adipogenic differentiation and Oil Red O staining}

MCF10A-NeuT cells expressing various mutants of Ppary 1 were maintained at confluence for 2 days and treated with vehicle control or ligand for 2 days. Oil Red $\mathrm{O}$ staining of cells has been previously described [43].

\section{Microarray analysis}

Total RNA was isolated from MCF10A-NeuT cells transduced with Ppar 1 or acetylation defective mutant after adipogenic differentiation protocol. RNA quality was determined by an Agilent 2100 bioanalyzer. Probe synthesis and hybridization to Affymetrix gene chips, human gene 1.0 ST array (Affymetrix, Santa Clara, CA) were performed according to the manufacturer's manual. Chips were scanned on an Affymetrix Gene Chip Scanner 3000, using Command Console Software. Background correction and normalization were done using Iterative plier 16 with GeneSpring V12.0 software (Agilent, Palo Alto, CA, USA). 1.5-fold ( $p$ value $<0.05$ ) differentially expressed gene list was generated. The differentially expressed gene list was loaded into Ingenuity Pathway Analyses (IPA) 8.0 software (http://www.ingenuity.com) to perform biological network and functional analysis. Expression profiles are displayed using Treeview. Microarray analysis was also performed with total RNA samples from Sirt1 $1^{+/+}$and Sirt1 $1^{-/-}$mice liver [28]. Pathway analysis was performed using and Kyoto Encyclopedia of Genes and Genomes (KEGG). Gene Ontology (GO) analysis was performed for gene functions.

\section{ACKNOWLEDGEMENTS}

This work was supported in part by R01CA70896, R01CA75503, R01CA86072 (R.G.P.), RO1 DK073466 (A.A.S.), K08DK094968 (R.E.S), and Ellison Medical Foundation New Scholar Award in Aging (A.A.S.). The Sidney Kimmel Cancer Center was supported by the NIH Cancer Center Core Grant P30CA56036 (R.G.P). This project is funded in part from the Dr. Ralph and Marian C. Falk Medical Research Trust (R.G.P) and a grant from the Pennsylvania Department of Health (R.G.P., C.W.). The Department specifically disclaims responsibility for analyses, interpretations or conclusions.

\section{COMPETINGNG FINANCIAL INTERESTS}

The authors declare no competing financial interests.

\section{REFERENCES}

1. Mueller E, Sarraf P, Tontonoz P, Evans RM, Martin KJ, Zhang M, Fletcher C, Singer S, and Spiegelman BM. Terminal differentiation of human breast cancer through PPAR gamma. Mol Cell 1998; 1: 465-470.

2. Tontonoz P, Graves RA, Budavari AI, ErdjumentBromage H, Lui M, Hu E, Tempst P, and Spiegelman BM. Adipocyte-specific transcription factor ARF6 is a heterodimeric complex of two nuclear hormone receptors, PPAR gamma and RXR alpha. Nucleic Acids Res 1994; 22: 5628-5634.

3. Jiang C, Ting AT, and Seed B. PPAR-gamma agonists inhibit production of monocyte inflammatory cytokines. Nature 1998; 391: 82-86.

4. Miles PD, Barak Y, He W, Evans RM, and Olefsky JM. Improved insulin-sensitivity in mice heterozygous for PPAR-gamma deficiency. J Clin Invest 2000; 105: 287-292.

5. Wang AC, Dai X, Luu B, and Conrad DJ. Peroxisome proliferator-activated receptor-gamma regulates airway epithelial cell activation. Am J Respir Cell Mol Biol 2001; 24: 688-693. 
6. Zhou J, Zhang W, Liang B, Casimiro MC, WhitakerMenezes D, Wang M, Lisanti MP, Lanza-Jacoby S, Pestell RG, and Wang C. PPARgamma activation induces autophagy in breast cancer cells. Int J Biochem Cell Biol 2009; 41: 2334-2342.

7. $\mathrm{Hu}$ E, Kim JB, Sarraf P, and Spiegelman BM. Inhibition of adipogenesis through MAP kinase-mediated phosphorylation of PPAR $\gamma$. Science 1996; 274: 2100-2103.

8. Camp HS, and Tafuri SR. Regulation of peroxisome proliferator-activated receptor $\gamma$ activity by mitogenactivated protein kinase. J Biol Chem 1997; 272: 1081110816.

9. Zhang B, Berger J, Zhou G, Elbrecht A, Biswas S, WhiteCarrington S, Szalkowski D, Moller DE. Insulin- and mitogen-activated protein kinase-mediated phosphorylation and activation of peroxisome proliferator-activated receptor . J Biol Chem 1996; 271: 31771-31774.

10. Iankova I, Petersen RK, Annicotte JS, Chavey C, Hansen JB, Kratchmarova I, Sarruf D, Benkirane M, Kristiansen K, Fajas L. Peroxisome proliferator-activated receptor $\gamma$ recruits the positive transcription elongation factor $b$ complex to activate transcription and promote adipogenesis. Mol Endocrinol 2006; 20: 1494-1505.

11. Compe E, Drané P, Laurent C, Diderich K, Braun C, Hoeijmakers JH, Egly JM. Dysregulation of the peroxisome proliferator-activated receptor target genes by XPD mutations. Mol Cell Biol 2005; 25: 6065-6076.

12. Choi JH, Banks AS, Estall JL, Kajimura S, Boström P, Laznik D, Ruas JL, Chalmers MJ, Kamenecka TM, Blüher M, Griffin PR, Spiegelman BM. Anti-diabetic drugs inhibit obesity-linked phosphorylation of PPAR $\gamma$ by Cdk5. Nature 2010; 466: 451-456.

13. Kim MY, Woo EM, Chong YT, Homenko DR, Kraus WL. Acetylation of estrogen receptor alpha by p300 at lysines 266 and 268 enhances the deoxyribonucleic acid binding and transactivation activities of the receptor. Mol Endocrinol. 2006; 20: 1479-93.

14. Wang C, Fu M, Angeletti RH, Siconolfi-Baez L, Reutens AT, Albanese C, Lisanti MP, Katzenellenbogen BS, Kato S, Hopp T, Fuqua SA, Lopez GN, Kushner PJ, Pestell RG. Direct acetylation of the estrogen receptor alpha hinge region by $\mathrm{p} 300$ regulates transactivation and hormone sensitivity. J Biol Chem 2001; 276: 18375-18383.

15. Han L, Zhou R, Niu J, McNutt MA, Wang P, Tong T. SIRT1 is regulated by a PPAR $\{\gamma\}$-SIRT1 negative feedback loop associated with senescence. Nucleic Acids Res. 2010; 38:7458-7471.

16. Qiang L, Wang L, Kon N, Zhao W, Lee S, Zhang Y, Rosenbaum M, Zhao Y, Gu W, Farmer SR, Accili D. Brown remodeling of white adipose tissue by SirT1dependent deacetylation of Ppargamma. Cell 2012; 150: 620-632.

17. Fu M, Wang C, Reutens AT, Wang J, Angeletti RH, Siconolfi-Baez L, Ogryzko V, Avantaggiati ML, Pestell
RG. p300 and p300/cAMP-response element-binding protein-associated factor acetylate the androgen receptor at sites governing hormone-dependent transactivation. J Biol Chem 2000; 275: 20853-20860.

18. Daniel AR, Gaviglio AL, Czaplicki LM, Hillard CJ, Housa $\mathrm{D}$, Lange CA. The progesterone receptor hinge region regulates the kinetics of transcriptional responses through acetylation, phosphorylation, and nuclear retention. Mol Endocrinol 2010; 24: 2126-38.

19. Kino T, Chrousos GP. Acetylation-mediated epigenetic regulation of glucocorticoid receptor activity: circadian rhythm-associated alterations of glucocorticoid actions in target tissues. Mol Cell Endocrinol 2011; 336: 23-30.

20. Kourtidis A, Srinivasaiah R, Carkner RD, Brosnan MJ, and Conklin DS. Peroxisome proliferator-activated receptorgamma protects ERBB2-positive breast cancer cells from palmitate toxicity. Breast cancer research 2009; 11: R16.

21. Tian L, Zhou J, Casimiro MC, Liang B, Ojeifo JO, Wang M, Hyslop T, Wang C, Pestell RG. Activating peroxisome proliferator-activated receptor gamma mutant promotes tumor growth in vivo by enhancing angiogenesis. Cancer Res 2009; 69: 9236-9244.

22. Villar-Garea A, Israel L, and Imhof A. Analysis of histone modifications by mass spectrometry. Current protocols in protein science / editorial board, John E. Coligan ... [et al.] 2008; Chapter 14: Unit 1410

23. Lee HA, Lee DY, Cho HM, Kim SY, Iwasaki Y, Kim IK. Histone deacetylase inhibition attenuates transcriptional activity of mineralocorticoid receptor through its acetylation and prevents development of hypertension. Circ Res 2013; 112: 1004-12.

24. Soutoglou E, Katrakili N, Talianidis I. Acetylation regulates transcription factor activity at multiple levels. Mol Cell 2000; 5: 745-51.

25. Jacob AL, Lund J, Martinez P, Hedin L. Acetylation of steroidogenic factor 1 protein regulates its transcriptional activity and recruits the coactivator GCN5. J Biol Chem 2001; 276: 37659-64.

26. Tontonoz P, Hu E, Spiegelman BM. Stimulation of adipogenesis in fibroblasts by PPAR gamma 2, a lipidactivated transcription factor. Cell 1994; 79:1147-56.

27. Picard F, Kurtev M, Chung N, Topark-Ngarm A, Senawong T, Machado De Oliveira R, Leid M, McBurney MW, Guarente L. Sirt1 promotes fat mobilization in white adipocytes by repressing PPAR-gamma. Nature 2004; 429: 771-6.

28. Powell MJ, Casimiro MC, Cordon-Cardo C, He X, Yeow WS, Wang C, McCue PA, McBurney MW, Pestell RG. Disruption of a Sirt1-dependent autophagy checkpoint in the prostate results in prostatic intraepithelial neoplasia lesion formation. Cancer Res 2011; 71: 964-75.

29. Yu S, Matsusue K, Kashireddy P, Cao WQ, Yeldandi V, Yeldandi AV, Rao MS, Gonzalez FJ, Reddy JK. Adipocytespecific gene expression and adipogenic steatosis in the 
mouse liver due to peroxisome proliferator-activated receptor gammal (PPARgamma1) overexpression. J Biol Chem 2003; 278: 498-505.

30. Pascual G, Fong AL, Ogawa S, Gamliel A, Li AC, Perissi V, Rose DW, Willson TM, Rosenfeld MG, Glass CK. A SUMOylation-dependent pathway mediates transrepression of inflammatory response genes by PPAR-gamma. Nature 2005; 437: 759-763

31. Yamashita D, Yamaguchi T, Shimizu M, Nakata N, Hirose $\mathrm{F}$, Osumi T. The transactivating function of peroxisome proliferator-activated receptor gamma is negatively regulated by SUMO conjugation in the amino-terminal domain. Genes Cells 2004; 9: 1017-29.

32. Walker AK, Yang F, Jiang K, Ji JY, Watts JL, Purushotham A, Boss O, Hirsch ML, Ribich S, Smith JJ, Israelian K, Westphal CH, Rodgers JT, Shioda T, Elson SL,Mulligan P, Najafi-Shoushtari H, Black JC, Thakur JK, Kadyk LC, Whetstine JR, Mostoslavsky R, Puigserver P, Li X, Dyson NJ, Hart AC, Näär AM. Conserved role of SIRT1 orthologs in fasting-dependent inhibition of the lipid/cholesterol regulator SREBP. Genes Dev. 2010; 24:1403-17.

33. Ponugoti B, Kim DH, Xiao Z, Smith Z, Miao J, Zang M, Wu SY, Chiang CM, Veenstra TD, Kemper JK. SIRT1 deacetylates and inhibits SREBP-1C activity in regulation of hepatic lipid metabolism. J Biol Chem. 2010; 285:3395970 .

34. Li X, Zhang S, Blander G, Tse JG, Krieger M, and Guarente L. SIRT1 deacetylates and positively regulates the nuclear receptor LXR. Mol Cell 2007; 28: 91-106.

35. Kemper JK, Xiao Z, Ponugoti B, Miao J, Fang S, Kanamaluru D, Tsang S, Wu SY, Chiang CM, Veenstra TD. FXR acetylation is normally dynamically regulated by p300 and SIRT1 but constitutively elevated in metabolic disease states. Cell Metab 2009; 10: 392-404.

36. Ward PS, and Thompson CB. Metabolic reprogramming: a cancer hallmark even warburg did not anticipate. Cancer Cell 2012; 21: 297-308.

37. Wang X, Sun Y, Wong J, Conklin DS. PPAR $\gamma$ maintains ERBB2-positive breast cancer stem cells. Oncogene 2013; 32: 5512-21.

38. Liu M, Ju X, Willmarth NE, Casimiro MC, Ojeifo J, Sakamaki T, Katiyar S, Jiao X, Popov VM, Yu Z, Wu K, Joyce D, Wang C, Pestell RG. Nuclear factor-kappaB enhances ErbB2-induced mammary tumorigenesis and neoangiogenesis in vivo. Am J Pathol 2009; 174: 19101920.

39. Wang $\mathrm{C}, \mathrm{Fu} \mathrm{M}$, D'Amico M, Albanese C, Zhou JN, Brownlee M, Lisanti MP, Chatterjee VK, Lazar MA, Pestell RG. Inhibition of cellular proliferation through IkappaB kinase-independent and peroxisome proliferator-activated receptor gamma-dependent repression of cyclin D1. Mol Cell Biol 2001; 21: 3057-3070.

40. Floyd ZE, and Stephens JM. Control of peroxisome proliferator-activated receptor gamma 2 stability and activity by SUMOylation. Obes Res 2004; 12: 921-928.

41. Brunet A, Sweeney LB, Sturgill JF, Chua KF, Greer PL, Lin Y, Tran H, Ross SE, Mostoslavsky R, Cohen HY, Hu LS, Cheng HL, Jedrychowski MP, Gygi SP,Sinclair DA, Alt FW, Greenberg ME. Stress-dependent regulation of FOXO transcription factors by the SIRT1 deacetylase. Science 2004; 303: 2011-2015.

42. Sakamaki T, Casimiro MC, Ju X, Quong AA, Katiyar S, Liu M, Jiao X, Li A, Zhang X, Lu Y, Wang C, Byers S, Nicholson R, Link T, Shemluck M, Yang J, Fricke ST, Novikoff PM, Papanikolaou A, Arnold A, Albanese C, Pestell R. Cyclin D1 determines mitochondrial function . Mol Cell Biol 2006; 26: 5449-5469.

43. Wang C, Pattabiraman N, Zhou JN, Fu M, Sakamaki T, Albanese C, Li Z, Wu K, Hulit J, Neumeister P, Novikoff PM, Brownlee M, Scherer PE, Jones JG, Whitney KD, Donehower LA, Harris EL, Rohan T, Johns DC, Pestell RG. Cyclin D1 repression of peroxisome proliferator-activated receptor gamma expression and transactivation. Mol Cell Biol 2003; 23: 6159-6173.

44. Gu W, and Roeder RG. Activation of p53 sequence-specific DNA binding by acetylation of the p53 C-terminal domain. Cell 1997; 90: 595-606. 